\title{
Anthós
}

8-3-2017

\section{Land Use Zoning in America: The Case for Inclusionary Policy}

Thomas Geffner

Portland State University

Follow this and additional works at: https://pdxscholar.library.pdx.edu/anthos

Part of the Cultural Resource Management and Policy Analysis Commons, and the Urban, Community and Regional Planning Commons

Let us know how access to this document benefits you.

\section{Recommended Citation}

Geffner, Thomas (2017) "Land Use Zoning in America: The Case for Inclusionary Policy," Anthós: Vol. 8: Iss. 1, Article 5.

https://doi.org/10.15760/anthos.2017.49

This open access Article is distributed under the terms of the Creative Commons Attribution-NonCommercialShareAlike 4.0 International License (CC BY-NC-SA 4.0). All documents in PDXScholar should meet accessibility standards. If we can make this document more accessible to you, contact our team. 


\section{Land Use Zoning In America:}

\section{The Case for Inclusionary Policy}

Thomas Geffner

Residential zoning code has been one of the most powerful forces in shaping the growth of modern American cities. By regulating which types of buildings can go where, zoning code has led to the creation of suburbs as we know them, with row after row of detached single-family homes. Indeed, the American city would look drastically different if it were not for the creation of zoning codes. But how did the institution that is American zoning come to exist? This essay will attempt to answer that question by exploring the early history of zoning, starting in the 1910s. It will also look at the impact of zoning on America's poorest residents. Has the division of residential zones into mostly large lots with minimum home sizes excluded the poor from the suburbs? The correlation between zoning and economic exclusion has been studied, and a strong connection discovered. Given this, what can be done to remedy the problem? An alternative to current law, inclusionary zoning, has been explored and shows promise for fixing some of the problems that current zoning creates.

According to the Encyclopedia of Housing, zoning refers to the "enactment and enforcement of legislation by local governments to control the development of land by regulating its use" (Weinstien 2012, 791). This regulation, which controls features such as lot size and building height, allows municipalities to determine, with great precision, what type of buildings will get built in their towns. At a 
broader level, zoning allows for the forced separation of land uses. It is this part of zoning that is most easily noticeable: the majority of suburban communities in America exist as they do because of landuse separations.

Zoning has existed for hundreds of years. In ancient China, writer Kuan-Tzu spoke of the benefits of land-use separation (Salsich 2003). The actual practice of zoning as a means of control started in Germany in the 1880s in the suburb of Altona (Weinstein 2012). The export of zoning to America began in the early 1900s. For city planners, zoning was seen as a way to steer urban development in a direction that would benefit the community as a whole. For real estate developers and business owners, zoning was a useful tool to maintain property values (Weinstein 2012). In addition to support from intellectuals and special interests, zoning was extremely popular among the public (Fischel 2001). It is this broad appeal that allowed zoning to rapidly take off in America. By 1916, eight cities had some form of zoning ordinance in place, and over the next 20 years, an additional 1300 municipalities adopted land control techniques (Fischel 2001).

Zoning was first implemented in America in New York City during 1916 (Weinstein 2012) to control rampant overcrowding (Salsich 2003). In 1924, the US Chamber of Commerce created the Standard State Zoning Enabling Act (SZEA). The SZEA created a standard framework that states could follow in order to implement zoning (University of Pennsylvania Law Review 312). It established zoning as a "police power" that did not require amendments to a state's constitution in order to be legal (Standard State 1924). Two 
years later, the Supreme Court weighed in on the legality of zoning in the landmark case of Village of Euclid v. Ambler Realty Company. The court sided with the Chamber of Commerce, again emphasizing that zoning was a legitimate use of police power (Weinstein 2012). After this decision, the legality of zoning was unarguable. As zoning had passed through both legislative and judicial branches at the federal level, states were encouraged to create comprehensive zoning plans. By 1930, 80\% of America's urban population lived in municipalities with zoning controls, many of which were patterned off of the 1916 New York ordinance (Weinstein 2012).

For the municipal government, zoning was a welcome addition to city code. As developments in public transit allowed a steady stream of workers to flock to suburban housing, newly incorporated fringe cities faced massive increases in population. These once quiet municipalities were unprepared for the growth. As subdivisions were built at a rapid pace, cities faced the prospect of expensive infrastructure construction. By zoning large minimum lot sizes, the towns were able to limit the money that they would need to spend on services (Fischel 2001). Additionally, as noted by Fischel, zoning helped enable towns to levy efficient property taxes, and guarantee high tax returns by limiting the economic makeup of communities.

Among homeowners, zoning was equally embraced. As workers moved out of the cities and bought suburban houses, they sought ways to protect their investments. A home was, in most cases, the biggest capital asset that an individual would ever own, so homebuyers logically feared anything that might cause their property 
values to lower. These fears led homeowners to support residential zones that were free of commercial and industrial institutions and were made up of people of the same socioeconomic class. Development patterns prior to zoning laws reflected these desires. In an attempt to appeal to the masses, developers created neighborhoods of homogenous income and attempted to control land-use in their subdivisions (Fishcel 2001). In order to shield communities from encroaching commercial and industrial uses, subdividers utilized protective covenants. However, these protective covenants were only able to control lands within the subdivision; outside these areas was a free-for-all where "incompatible uses" existed (Fischel 2001). Homeowners were fearful of these "incompatible uses," especially multifamily dwellings (Salsich 2003). In order to receive the protection that failed covenants could not provide, residents turned to their municipal governments, pressuring local administration to adopt zoning codes.

Although zoning has been seen as a great gift for the middleclass homeowner, not all members of society have benefited from these exclusive ordinances. By limiting the development of multifamily (apartment) housing, zoning has reduced the supply of dwellings that are within reach for the poorest Americans. Opposition to adjacent apartment communities has long been an issue for singlefamily homeowners. The general societal distaste of multifamily housing was well reflected in cases heard in the courts, and when presiding over Euclid v. Ambler, Justice Sutherland delivered an opinion referring to apartment houses as "a mere parasite, constructed in order to take advantage of the open spaces and attractive 52 
surroundings created by the residential character of the [single-family home] district" (Euclid v Ambler 1926). Large-scale single-family zoning offered homeowners safety from these 'parasitic' dwellings. When multifamily development is excluded from a residential zone, families who cannot afford a single-family home are locked out of the region. A report published by the American Planning Association (APA) which looked at multifamily housing, zoning policy and affordability across several different cities in the United States found that zoning regulations can indeed serve as a barrier in the creation of multifamily housing. Although apartment housing is not always affordable (and single-family homes are not always expensive), the APA found that communities with the most barriers to multi-family housing development were often the most expensive (Knapp 2007). Zoning has been found to increase the price of single-family homes, which provides a further barrier for low income families. Although the extent of this effect has been argued, a review of the literature conducted by Quigley and Rosenthal concludes that "a number of credible papers seem to bear out theoretical expectations [that zoning limits the supply of buildable land and thus leads to larger and more expensive homes]" (Quigley 2005). Salsich and Glaeser, two prominent researchers studying the impact of zoning, investigate cost increases due to zoning. Salsich looks at growth management efforts in Florida, finding that they have led to "reduced housing affordability in a statistically significant character" (Salsich 2003, pg. 8). He draws upon previous scholarship to show six zoning techniques that effectively exclude poor residents. These techniques include control over lots (size and frontage requirements), control over housing size 
(minimum square footage and maximum bedroom numbers) and control over accessory structures (restrictions on mobile homes and multiple dwellings per lot) (Salsich 2003). By mandating lot sizes, zoning restricts buildable land, which in turn lowers the housing supply. The supply of land is an important part of Glaeser's work on housing affordability. He identifies that housing costs across the country are for the most part close to construction costs (Glaeser 2002). The implication of this is that in expensive areas of the country, such as New York, Portland or San Francisco, high housing prices are tied to land value. By limiting the buildable supply of land, zoning artificially inflates land costs, leading to an affordability crisis (Glaeser 2002).

Due to the inequalities caused by zoning law, courts have begun to discuss the legality of these laws. As noted in the University of Pennsylvania Law Review, zoning can deny equal protection under the law for poor citizens (1972). In 1975 and 1983, the New Jersey Supreme Court passed a series of decisions known as the Mount Laurel Doctrine which required municipalities to actively address the issue of affordable housing. Although the doctrine has provided a concrete framework, it has simply not been upheld in practice (Talbert 2005). While zoning can be amended at a local scale, court hearings of this type are problematic because participation is limited to developers and neighboring residents (University of Pennsylvania Law Review 1972). This has the unfortunate effect of excluding members of the community who would advocate to change the zoning code. Zoning is implemented at a municipal level, meaning that court decisions at a statewide or higher level are unlikely to remedy the 
situation. Also, due to the ruling that zoning is a police power, it can be challenging for community members to have their voices heard regarding zoning issues. Finally, owing to the precedent of Euclid v Ambler, the courts as a whole favor the idea of zoning, having reinforced it as a reasonable use of the police power. The University of Pennsylvania Law Review has concluded that the many barriers to effective litigation render it extremely unlikely that a solution to America's zoning problem can and will be found in the courts (1972).

It would seem as though zoning in America is here to stay. Powerful factors have helped to entrench the practice of zoning in American society. These factors include homeowners, who seek to protect their assets, as well as judicial decisions continually affirming the legitimacy of zoning. However, there is increasing pressure to reform zoning law from social justice advocates and community organizers. It is clear that a change to this institution is necessary. The technique of inclusionary zoning has been explored by communities as a way to right the inequities that zoning has caused.

Where traditional, also known as exclusionary zoning, tends to limit the economic makeup of neighborhoods, inclusionary zoning does just the opposite, helping to foster diversity (Talbert 2005). This goal is accomplished by mandating that a certain percentage of units in new developments be "affordable." The definition of "affordable" is set by the municipality or state undertaking the inclusionary zoning, and usually is designed to be accessible for families making less than $80 \%$ of the median income. In addition, inclusionary zoning typically includes concessions or buyouts to developers in exchange for providing the affordable units (Talbert 2005). Several scholars have 
advocated this technique as a potential solution to the affordable housing crisis in America (Salsich 2003, Blaesser et. Al. 2002, The University of Pennsylvania Law Review 1972).

There are a number of successful examples of inclusionary zoning in America. According to Talbert, this technique has produced over 100,000 units as of 2005 (Talbert 2005). Specific communities that have been successful in implementing inclusionary zoning include Cambridge, Massachusetts (Blaesser et. Al. 2002) and the Miami Valley region in Ohio (The University of Pennsylvania Law Review 1972). Overall, the inclusionary zoning movement is gaining momentum, and 24 states now have some level of comprehensive zoning law to address affordable housing concerns (Salsich 2003). However, municipalities interested in creating inclusionary zoning laws must be mindful, as there have been several notable failures of this technique, including Barnstable, Massachusetts (Blaesser et. al. 2002). Communities interested in inclusionary zoning should look to municipalities such as Cambridge and Miami Valley as guides.

The effective implementation of inclusionary zoning relies on several basic tenants. First, it is important to note that inclusionary zoning has faced controversy and litigation, and will continue to do so (Talbert 2005). Mandating that a certain percentage of units in a developments be affordable will likely reduce developers' returns. Many of the developers may be unwilling to trade potential profits for general societal benefit. However, as growth relies on developers, it will be incumbent for municipalities to cooperate with developers in order to create change. Indeed, the National Housing Conference 
suggests that municipalities work with developers when creating new inclusionary zoning laws (Blaesser et. al. 2002).

If inclusionary zoning laws are rigid to the point that they prevent developers from meaningful profits, these laws will likely be challenged in court, as happened in Barnstable. Traditionally, the courts have sided with developers in these cases, declaring it unconstitutional for the government to prevent an individual from receiving a reasonable return on their land. Preventing this profit is referred to as a "taking" (Blaesser et. al. 2002). In the case of Barnstable, the inclusionary zoning laws were found to constitute a "taking" and were thus labeled an "illegal tax" (Ibid, pg. 14).

It is possible for municipalities to offset the loss of profit by providing incentives to developers. Bobrowski suggests a system of "carrots and sticks" in order to win over developer support (Ibid, pg 7). The carrots in question can be provided in the form of density bonuses. Where mandatory set asides alone make profit difficult (Salsich 2003), this difficulty can be mitigated when developers are allowed to build an increased number of units on a given site. Density bonuses have been found to be an enticing solution by the University of Pennsylvania Law Review and Salsich (Salsich 2003, The University of Pennsylvania Law Review 1972). For cities, allowing higher density is a no-cost incentive, a trait that makes it especially appealing to municipalities that do not have large budgets for affordable housing.

Finally, for inclusionary zoning to be successful, it needs to be broad and flexible. A collection of overly specific rules and complicated regulations will slow the development process and bog 
down the creation of affordable housing. Inclusionary zoning is most successful if municipalities are open to change and are willing to consider situations on a case by case basis (Blaesser et. al. 2002). Again, cooperation with developers is necessary. If rules are too specific, developers will likely exploit this with the use of creative work-arounds, a phenomenon observed by the National Housing Council (Blaesser et. al. 2002).

Zoning represents a major paradigm in American housing. It has shaped, and continues to shape, residential development across the country. Although zoning has historically had a negative impact on the availability of affordable housing, it remains largely unchanged to this day. As housing prices continue to rise across the country, it has become necessary to rethink zoning codes in order to equally serve all Americans. The technique of inclusionary zoning is a way to meet the needs of poor citizens, while guarding home property values from unwelcome intrusion. Inclusionary zoning has faced some controversy. Regardless, early adoption in some communities has been encouraging, and its ability to create more affordable housing should outweigh any controversies. Municipalities looking to increase their supply of affordable housing would be wise to consider the possibility of inclusionary zoning.

\section{References:}

Blaesser, D., Bobrowski, M., Engler, R., Herr, P., Herzog, R., Jameson, D., Kayden, J., Kiely, M., and Ziegler, C. (2002). Inclusionary zoning: lessons learned in Massachusetts. (NHC 
Affordable Housing Policy Review 1st ed. Vol. 2.)

Washington, DC: National Housing Conference. Retrived

May 21, 2015, from http:/www.nhc.org/media/documents/

IZ_lessons_in_MA.pdf

Fischel, W. (2001). An economic history of zoning and a cure for its exclusionary effects. Urban Studies. 41(2), 317-340. doi: 10.1080/0042098032000165271.

Fischel, W. (1992). Property taxation and the tiebout model: evidence for the benefit view from zoning and voting. Journal of Economic Literature 30(1) 171-77. Retrieved from JSTOR. Retrieved from http://www.jstor.org/stable/2727882

Glaeser, E., Gyourko, J. (2002). The impact of zoning on housing affordability. Retrieved from Harvard University, Institute of Economic Research Web site: http://scholar.harvard.edu/ glaeser/publications/impact-zoning-housing-affordability

Knaap, G., Moore, T., Parker, R. (2007). Zoning as a Barrier to Multifamily Housing Development. (American Planning Association Rep. no. 548). Chicago, IL. Retrieved May 22, 2015, from http://www.huduser.org/portal/Publications/pdf/ zoning_MultifmlyDev.pdf

Quigley, J., Rosenthal, L. (2005). The effects of land use regulation on the price of housing: What do we know? What Can We Learn?" Cityscape 8(1), 69-109. Retrieved from http:// urbanpolicy.berkeley.edu/pdf/QR2005.pdf

Salsich, P. (2003). The impact of land use laws on affordable housing. Saint Louis, MO: East-West Gateway Council of 
Governments. Retrieved from http://www.ewgateway.org/ pdffiles/blueprintdocs/landuselaws.pdf

The Standard State Zoning Enabling Act (1924). Washington, DC:

U.S. Chamber of Commerce. Retrieved from https:// www.planning.org/growingsmart/pdf/SZEnablingAct1926.pdf

Talbert, C., Costa, N. (2005) Current issues in inclusionary zoning. The Urban Lawyer 37(3) 513-27. Retrieved on May 20, 2015 from JSTOR. Retrieved at http://www.jstor.org/stable/ 27895553

University of Pennsylvania Law Review. (1972). Toward improved housing opportunities: A new direction for zoning law. University of Pennsylvania Law Review 121(2): 330-350. Retrieved from JSTOR. Retrieved from http://www.jstor.org/ stable/3311165

Town of Euclid v. Ambler Realty Co. (1926). 272 U.S. 365 Retrieved from https://www.law.cornell.edu/supremecourt/text/272/365

Weinstein, A. (2012) Zoning. In Carswell, A (Ed.) The Encyclopedia of Housing (pp 790-794). Thousand Oaks, CA: SAGE Publications 